\title{
Occasional presence of herpes viruses in synovial fluid and blood from patients with rheumatoid arthritis and axial spondyloarthritis
}

\author{
Rubén Burgos $^{1}$ - Graciela Ordoñez ${ }^{2} \cdot$ Janitzia Vázquez-Mellado $^{1} \cdot$ Benjamín Pineda $^{2}$ • \\ Julio Sotelo ${ }^{2}$
}

Received: 24 February 2015 /Revised: 7 May 2015 / Accepted: 8 May 2015 /Published online: 17 May 2015

(C) The Author(s) 2015. This article is published with open access at Springerlink.com

\begin{abstract}
Viral agents have been suspected as participants of immune-mediated disorders. In the case of rheumatic diseases, the synovial joint cavity represents a secluded area of inflammation which could harbor etiological agents. We analyzed by polymerase chain reaction the possible presence of DNA from various herpes viruses in blood and synovial fluid from patients with either rheumatoid arthritis $(n=18)$, axial spondyloarthritis $(n=11)$, or osteoarthritis $(n=8)$. Relevant findings were as follows: DNA from varicella zoster virus was found in synovial fluid but not in blood mononuclear cells from $33 \%$ of patients with rheumatoid arthritis and in $45 \%$ of patients with axial spondyloarthritis but not in patients with osteoarthritis. Also, DNA from herpes simplex viruses 1 and 2 was found both in the blood and in the synovial fluid from $33 \%$ of patients with rheumatoid arthritis. Our results indicate the occasional presence of DNA from herpes viruses in patients with rheumatoid arthritis or with axial spondyloarthritis. However, these findings might represent a parallel epiphenomenon of viral activation associated either with immunosuppressive therapy or with primary immune disturbances, rather than the etiological participation of herpes viruses in these disorders.
\end{abstract}

Keywords Herpes simplex viruses · Varicella zoster virus . Viruses in axial spondyloarthritis · Viruses in rheumatoid arthritis · Viruses in synovial fluid

Julio Sotelo

jsotelo@unam.mx

1 Rheumatology Department, Hospital General de Mexico, Dr. Balmis 148, 06720 Mexico City, Mexico

2 Neuroimmunology Unit, National Institute of Neurology and Neurosurgery of Mexico, Insurgentes sur 3877, 14269 Mexico City, Mexico

\section{Introduction}

Rheumatoid arthritis (RA) is a chronic inflammatory disease of the synovium and other tissues; its origin is unknown but its immunopathology includes $\mathrm{T}$ cell and B cell abnormalities leading to autoimmunity. The cause of RA has been linked to the interaction of genetic susceptibility and environmental factors; infectious agents have long been suspected but no definitive data on the role of viral infections has been demonstrated [1-3]. Epstein-Barr virus (EBV), human herpes virus 6 (HHV6), and human parvovirus B19 have been weakly implicated in RA [4-10]; a recent study found no DNA from herpes simplex viruses 1 and 2 (HSV1-2) or varicella zoster virus (VZV) in peripheral blood cells and urine from RA patients $[1,11]$; the possible participation of measles virus has also been suggested [12]. A meta-analysis on the relation between methotrexate and viral infections in patients with RA did not show any significant association with VZV, whereas the association with HS was low [13]. However, the advent of novel immunosuppressive agents for the treatment of RA has also increased the risk of associated viral or bacterial infections. An increased risk of zoster in RA patients has been found [1,3], particularly in subjects older than 60 years and those under novel immunosuppressive treatment regimens [1], specifically, TNF antagonists like adalimumab, infliximab, and etanercept [3]. Similar risks for other herpes viruses have been described in patients under selective immunosuppressive therapy $[13,14]$.

A study on the synovial fluid and synovial membrane from patients with several rheumatic diseases using polymerase chain reaction (PCR) analysis was demonstrated in few cases of DNA from different viruses, including cytomegalovirus, parvovirus B1, Epstein-Barr virus, and herpes simplex; however, adenovirus or VZV were not found [15]. Thus far, an association between viral infections and axial spondyloarthritis (ASA) has not been reported. 
In multiple sclerosis (MS), another immune-mediated disorder, we have reported an association with VZV, including the finding of VZV in cerebrospinal fluid and in mononuclear cells from MS patients during active relapses of the disease [16]; RA and MS share genetic factors such as the DRB $1 *^{*} 04$ allele known to participate in both diseases, RA and MS [17, 18].

In this study, we aimed to identify DNA from various herpes viruses (VZV, HSV1 and 2, EBV, and HHV6) in the synovial fluid (SF) and peripheral blood mononuclear cells (PBMC) from patients either with active RA, with ASA, or with osteoarthritis (OA).

\section{Materials and methods}

\section{Patients}

A cross-sectional study was made with 15 adult patients with RA and 11 adult patients with ASA including cases with peripheral joint involvement, as well as in 8 patients with OA requiring synovial fluid drainage of at least one knee for therapeutic purposes. Patients were not included in the study if they had any previous trauma as cause of knee swelling or if they had been subjected to synovial fluid aspiration with or without glucocorticoid intra-articular injection in the last 3 months. In addition, patients having any symptom suggestive of infectious disease within the last week were not included. We also recorded demographic, therapeutic, and clinical data (Table 1). The institutional review board at each center approved the study's protocol; patients agreed to participate in the study by signing an informed consent form.

\section{Clinical samples}

Four milliliters of peripheral blood were treated with $0.02 \mathrm{ml}$ of ethylenediaminetetraacetic acid (EDTA); PBMC were separated by gradient centrifugation with Ficoll, and DNA was extracted with a kit Qiagen and precipitated with isopropanol. Also, $0.3 \mathrm{ml}$ of SF were treated with $400 \mu \mathrm{l}$ digestion buffer (500 mM tris, $\mathrm{pH}$ 9; $20 \mathrm{mM}$ EDTA, $10 \mathrm{mM}$ $\mathrm{NaCl}, 1 \%$ sodium dodecyl sulfate, $0.5 \mathrm{mg} / \mathrm{ml}$ de proteinase $\mathrm{K})$ for $18 \mathrm{~h}$ at $60^{\circ} \mathrm{C}$. Afterwards, proteins were precipitated with $100 \mu \mathrm{l}$ of protein precipitation solution (Qiagen). DNA was precipitated with isopropanol, dried at room temperature, and dissolved in $100 \mu \mathrm{l}$ of sterile water. No patient had previous history of herpes zoster.

\section{Determination of DNA from VZV, EBV, and HHV6}

The absolute quantification of viral load was made by realtime PCR. The primers and probes (Table 2) were derived from VZV, strain ORF 31 (gene gB), Epstein-Barr virus (gene gp85), and human herpes virus 6 (gene U29), and designed using Primer Express Software (Ver. 2.0); they were synthesized by Applied Biosystems (Mexico). The TaqMan probes were purchased from Applied Biosystems (Mexico). Each $25 \mu \mathrm{l}$ of PCR mixture contained $100 \mathrm{ng}$ of DNA either from blood mononuclear cells or from SF in $5 \mu$ of distilled water, plus $12.5 \mu \mathrm{l}$ of TaqMan universal PCR master mix (Applied Biosystems) and $1.25 \mu \mathrm{l}$ of primer mixture with a final concentration of each primer of $0.9 \mu \mathrm{M}$ and of each probe sequence of $0.25 \mu \mathrm{M}$. The TaqMan RNAse $\mathrm{P}$ was performed to normalize each sample. In addition, reaction mixtures containing the appropriate probe and primer system but without DNA were run on all plates by triplicate and used as negative controls. The PCR mixtures in 96-well microtiter plates were first incubated at $95^{\circ} \mathrm{C}$ for $10 \mathrm{~min}$, followed by 50 two-step cycles at $95^{\circ} \mathrm{C}$ for $10 \mathrm{~s}$ and at $60^{\circ} \mathrm{C}$ for $1 \mathrm{~min}$, using an ABI PRISM 7500 real-time PCR system (Applied Biosystems). For each reaction, real-time fluorescence values were measured as a function of the quantity of a reporter dye (6-carboxy-fluorescein $[\mathrm{FAM}]$ ) released during amplifications. A threshold cycle
Table 1 Demographic and clinical features of the population included in the study

\begin{tabular}{llll}
\hline & $\begin{array}{l}\text { Rheumatoid arthritis } \\
n=15\end{array}$ & $\begin{array}{l}\text { Axial spondyloarthritis } \\
n=11\end{array}$ & $\begin{array}{l}\text { Osteoarthritis } \\
n=8\end{array}$ \\
\hline Male & $3(18)$ & $7(64)$ & $4(50)$ \\
Female & $12(82)$ & $4(36)$ & $4(50)$ \\
Age, years, mean & $43 \pm 12$ & $36 \pm 9$ & $60 \pm 8$ \\
Disease duration, years, mean & $8 \pm 6$ & $12 \pm 7$ & $12 \pm 10$ \\
DAS 28 ESR, mean & $4.2(1.0)$ & - & - \\
BASDAI, mean & - & $3.7(2.4)$ & - \\
Methotrexate & $11(73)$ & $1(9)$ & 0 \\
Leflunomide & $2(18)$ & 0 & 0 \\
Sulfasalazine & $7(47)$ & $6(55)$ & 0 \\
Hydroxychloroquine & $2(18)$ & 0 & 0 \\
Prednisone & $8(17)$ & $1(9)$ & 0 \\
\hline
\end{tabular}

Number in parenthesis represent percentages 
Table 2 Oligonucleotide primers

\begin{tabular}{llllrr}
\hline Viral target & Gene & Forward primer & Reverse primer & TaqMan probe & Product size (pb) \\
\hline VZV & ORF-31 & 5'-CACAAAAACACCCGACTCGAA-3' & 5'-AAT GGC ACG AAC TCA ACT G-3' & 1299 T & 65 \\
EBV & gp85 & 5'-TCCGGCAGGTCCTTCGT-3' & 5'-CGAGTGACCGAGAAGGGAGAT-3' & 1523 T & 67 \\
HHV6 & U29 & 5'-TTGTCTGTTGTCATGCGTCA-3 & 5'-TCCCATACTGGAGCTTTGCT-3' & 713 T & 181 \\
\hline
\end{tabular}

(Ct) value for each sample was determined as the number of the first cycle at which the measured fluorescence exceeded the threshold limit (10 times the standard deviation of the baseline). $\mathrm{Ct}$ values observed for DNA samples were used to calculate the VZV concentration based on the standard curve for the plasmid-containing test sequence.

\section{Determination of DNA from HSV1 and 2}

The absolute quantification of HSV1-2 viral load was made by real-time PCR using HSV1 and 2 real-time PCR kit (Shanghai ZJ Bio-Tech Co.) according to the manufacturing specifications which included the sequences of the primers used. Briefly, a standard curve was generated by serial dilutions from $1 \times 10^{7}$ copies $/ \mathrm{ml}$ to $1 \times 10^{4}$ copies $/ \mathrm{ml}$. Each $40-\mu \mathrm{l}$ PCR mixture contained $100 \mathrm{ng}$ of DNA either from blood mononuclear cells or from SF in $4 \mu \mathrm{l}$ of distilled water, plus $35 \mu \mathrm{l}$ of reaction mix (Shanghai ZJ Bio-Tech Co.) and $0.4 \mu \mathrm{l}$ of enzyme mix with $0.1 \mu$ l of internal control. In addition, reaction mixtures containing the appropriate reaction mix but without DNA were run on all plates by triplicate and used as a negative control. The PCR mixtures in 96-well microtiter plates were first incubated at $37{ }^{\circ} \mathrm{C}$ for $2 \mathrm{~min}$, one cycle; $94{ }^{\circ} \mathrm{C}$ for $2 \mathrm{~min}$, one cycle; $93{ }^{\circ} \mathrm{C}$ for $15 \mathrm{~s}$ and $60{ }^{\circ} \mathrm{C}$ for $60 \mathrm{~s}$, 40 cycles, using an ABI PRISM 7500 real-time PCR system (Applied Biosystems). For each reaction, real-time fluorescence values were measured as a function of the quantity of a reporter dye (6-FAM) released during amplifications. $\mathrm{A} \mathrm{Ct}$ value for each sample was determined as the number of the first cycle at which the measured fluorescence exceeded the threshold limit (10 times the standard deviation of the baseline). $\mathrm{Ct}$ values observed for DNA standards were used to calculate the HSV1 and 2 amount based on the standard curve for the positive control included in the kit.

\section{IgG and IgM antibodies against HSV in SF and in serum}

Additionally, after the results of PCR were obtained, the serum and SF were studied for IgG and IgM antibodies to HSV 1. The Enzygnost Anti-HSV1 assays for the detection of HSVspecific IgG and IgM (DiaSorin) were made by the enzymelinked immunosorbent assay (ELISA) test as follows: Serum samples and SF were diluted 1:100. Samples and controls of $100 \mu \mathrm{l}$ (negative, positive, and cut-off) were added to each well and incubated for $1 \mathrm{~h}$ at $37^{\circ} \mathrm{C}$. After incubation, the plate was washed with wash buffer; $100 \mu$ working enzyme tracer was added to each well and incubated for $1 \mathrm{~h}$ at $37^{\circ} \mathrm{C}$. Afterwards, the plate was washed with a wash buffer. Chromogen/ substrate of $100 \mu \mathrm{l}$ was added and incubated for $30 \mathrm{~min}$ at room temperature, in the dark. Finally, $200 \mu \mathrm{l}$ stop solution was added and the plate was read as absorbance values at 450/ $630 \mathrm{~nm}$ using a Labsystems Uniskan II plate reader. Samples with absorbance values greater than or equal to the cut-off value were considered positive and negative when the values were less than the cut-off value.

\section{Results}

We studied 15 patients with RA, 11 with ASA, and 8 with OA. Mean disease duration was $8 \pm 6$ years in patients with RA, 12 \pm 7 years in those with ASA, and $12 \pm 10$ years in those with OA. Demographic and clinical data is shown in Table 1. Most patients with RA were on treatment with disease-modifying antirheumatic drugs (DMARD), methotrexate, sulfasalazine, and prednisone; two on leflunomide; and two on hydroxychloroquine. Six patients with ASA received sulfasalazine, one methotrexate, and one prednisone. Regarding biologic therapy, one patient with RA was receiving rituximab and two with ASA were receiving infliximab.

Two relevant findings emerged from the molecular analysis in search for herpes viruses in PBMC and in SF (Table 3): (1) VZV DNA was found in the SF of a significant number of patients either with RA (33\%) or with ASA (45\%); however, VZV DNA was not found in the PBMC in any case. In contrast, VZV was absent in both PBMC and SF from patients with OA. (2) DNA from HSV1-2 was found in PBMC from 5 (33\%) patients as well as in the SF from $5(33 \%)$ patients with RA; these viruses were not detected in PBMC or SF from patients either with ASA or with OA (Tables 3 and 4).

In the analysis of HSV1-2, a coincidence of positive findings both in PBMC and in SF from RA patients was observed in four out of five positive cases (cases 5, 6, 7, and 8). Also, a high load of viral DNA from HSV1-2 was observed in two patients with RA (cases 6 and 7) as compared with the other positive cases, who had a far lower viral load (cases 4, 5, 8, and 15) (Table 3). Analysis of antibodies (IgG and IgM) against HSV did not show correlative results in serum and SF, nor among positive and negative cases in the PCR analysis; results were positive in about $50 \%$ of all 
Table 3 RT/PCR in PBMC and synovial fluid for herpes viruses

\begin{tabular}{|c|c|c|c|c|c|c|c|c|c|}
\hline \multirow[t]{2}{*}{ Case no. } & \multirow[t]{2}{*}{ Diagnosis } & \multicolumn{4}{|l|}{ PBMC } & \multicolumn{4}{|l|}{ Synovial fluid } \\
\hline & & VZV (\# copies) & HSV1/HSV2 (\# copies) & EBV & HHV6 & VZV (\# copies) & HSV1/HSV2 (\# copies) & EBV & HHV6 \\
\hline 1 & RA & 0 & 0 & - & - & 0 & 0 & + & - \\
\hline 2 & RA & 0 & 0 & + & - & 772 & 0 & - & - \\
\hline 3 & RA & 0 & 0 & - & - & 1005 & 0 & + & - \\
\hline 4 & RA & 0 & 137 & + & - & 0 & 0 & - & - \\
\hline 5 & RA & 0 & 556 & + & - & 116 & 80 & + & - \\
\hline 6 & RA & 0 & $1,400,567$ & - & - & 0 & 6344 & + & - \\
\hline 7 & RA & 0 & 710,228 & + & - & 0 & 854,725 & + & - \\
\hline 8 & RA & 0 & 479 & + & - & 0 & 641 & - & - \\
\hline 9 & RA & 0 & 0 & + & - & 0 & 0 & - & - \\
\hline 10 & RA & 0 & 0 & - & - & 0 & 0 & - & - \\
\hline 11 & RA & 0 & 0 & + & - & 189 & 0 & + & - \\
\hline 12 & RA & 0 & 0 & - & - & 0 & 0 & + & - \\
\hline 13 & RA & 0 & 0 & - & - & 0 & 0 & - & - \\
\hline 14 & RA & 0 & 0 & - & - & 0 & 0 & - & - \\
\hline 15 & RA & 0 & 0 & - & - & 1441 & 936 & - & - \\
\hline 16 & ASA & 0 & 0 & + & - & 2313 & 0 & + & - \\
\hline 17 & ASA & 0 & 0 & - & - & 0 & 0 & - & - \\
\hline 18 & ASA & 0 & 0 & - & - & 1516 & 0 & - & - \\
\hline 19 & ASA & 0 & 0 & - & - & 2252 & 0 & - & - \\
\hline 20 & ASA & 0 & 0 & - & - & 0 & 0 & + & - \\
\hline 21 & ASA & 0 & 0 & - & - & 0 & 0 & - & - \\
\hline 22 & ASA & 0 & 0 & - & - & 0 & 0 & - & - \\
\hline 23 & ASA & 0 & 0 & - & - & 140 & 0 & + & - \\
\hline 24 & ASA & 0 & 0 & - & - & 0 & 0 & - & - \\
\hline 25 & ASA & 0 & 0 & - & - & 0 & 0 & - & - \\
\hline 26 & ASA & 0 & 0 & + & - & 187 & 0 & - & - \\
\hline 27 & $\mathrm{OA}$ & 0 & 0 & - & - & 0 & 0 & + & - \\
\hline 28 & OA & 0 & 0 & + & - & 0 & 0 & - & - \\
\hline 29 & OA & 0 & 0 & + & - & 0 & 0 & - & - \\
\hline 30 & OA & 0 & 0 & - & - & 0 & 0 & - & - \\
\hline 31 & OA & 0 & 0 & - & - & 0 & 0 & - & - \\
\hline 32 & OA & 0 & 0 & - & - & 0 & 0 & - & - \\
\hline 33 & OA & 0 & 0 & - & - & 0 & 0 & - & - \\
\hline 34 & OA & 0 & 0 & - & - & 0 & 0 & - & - \\
\hline
\end{tabular}

Table 4 DNA from herpes viruses in PBMC and synovial fluid from patients with rheumatoid arthritis, axial spondyloarthritis, or osteoarthritis

\begin{tabular}{|c|c|c|c|c|c|c|c|c|}
\hline \multirow[t]{2}{*}{ Diagnosis } & \multicolumn{4}{|l|}{ PBMC } & \multicolumn{4}{|c|}{ Synovial fluid } \\
\hline & $\mathrm{VZV}+(\%)$ & HSV1/HSV2+ (\%) & $\mathrm{EBV}+(\%)$ & HHV6+ (\%) & $\mathrm{VZV}+(\%)$ & HSV1/HSV2+ (\%) & $\mathrm{EBV}+(\%)$ & HHV6+ (\%) \\
\hline RA $(n=15)$ & 0 & $5(33)$ & $7(47)$ & 0 & $5(33)$ & $5(33)$ & $7(47)$ & 0 \\
\hline $\operatorname{ASA}(n=11)$ & 0 & 0 & $2(18)$ & 0 & $5(45)$ & 0 & $3(27)$ & 0 \\
\hline $\mathrm{OA}(n=8)$ & 0 & 0 & $2(25)$ & 0 & 0 & 0 & $1(13)$ & 0 \\
\hline Total $(n=34)$ & 0 & $5(15)$ & $11(32)$ & 0 & $10(29)$ & $5(15)$ & $11(32)$ & 0 \\
\hline
\end{tabular}

$R A$ rheumatoid arthritis, $A S A$ axial spondyloarthritis, $O A$ osteoarthritis, $P B M C$ peripheral blood mononuclear cells 
samples, regardless on the group source of the specimen (results not shown).

Positive results for DNA from EBV in both PBMC and SF were frequent in patients from all three groups, although the percentage was higher but statistically non-significant for RA patients ( $47 \%$ in PBMC and $47 \%$ in SF) than for ASA (18 and $27 \%$ ) or OA patients (25 and $13 \%$ ). Also, a high concordance was observed between positive samples for EBV in PBMC and in SF (Table 4). The findings of positive cases for EBV in PBMC were similar to those found by us in healthy controls in previous studies [16].

\section{Discussion}

Our study discloses some intriguing features in regard to the potential participation of herpes viruses in RA and ASA. First, the conspicuous participation of a herpes virus in any of the three disorders studied was not observed (RA, ASA, or OA). Nonetheless, herpes simplex virus was found in one third of RA cases; the simultaneous presence of DNA from HSV1-2 in blood and in synovial joint cavity of most positive cases (four out of five) indicates a possible association of HSV with the immunological disturbances of some patients with RA; nevertheless, the relatively low frequency of positive cases does not support the idea of an etiological link. The finding of viral DNA in the SF of the actively inflamed joint might have two explanations, either the viral DNA was passively carried by leucocytes migrating from the blood to the SF or HSV was in actual replication within the synovial membrane as an epiphenomenon related with the systemic immune disturbances associated to RA. Less probable would be a direct etiological link of HSV1-2 infection as a trigger for the immune-related pathophysiology of RA; the most relevant argument against this speculation is the absence of these viruses in two thirds of RA cases studied. Currently, we are searching by ultrastructural studies the possible presence of viral particles in the SF of positive cases for PCR analysis, which would indicate an actual local replication of viruses, rather than the passive carriage of viral DNA by blood leukocytes to the synovial space. It is noteworthy that the amount of HSV copies was rather high in PBMC and SF from two patients with RA (cases 6 and 7, Table 3); however, the absence of these viruses in other similar cases precludes the speculation of a potential etiological participation.

Also difficult to explain is the finding of VZV DNA in the synovial joint cavity in about one third of patients either with RA or with ASA, whereas no viral DNA was found in the PBMC from the same patients. In another immune-mediated disorder, multiple sclerosis (MS), we have demonstrated a high content of VZV DNA and viral particles within the cerebrospinal fluid, which, similarly with the synovial space in RA, the subarachnoid space in MS represents a secluded area related with the pathophysiology of the disease [16]. The finding of VZV in a high percentage of MS cases was restricted to the relapse period of disease. However, in comparison with MS cases, in RA patients, the finding of VZV DNA was infrequent even when all clinical samples from RA patients included in this study were taken during periods of inflammatory activity. Additionally, in the case of RA and ASA, the absence of VZV DNA in two thirds of cases, and the absence of VZV DNA in the PBMC from those cases that were positive in SF, as well as the relatively low number of viral copies found within the synovial space makes remote the possibility of a potential causal association of VZV either with RA or with ASA. Nevertheless, the sporadic demonstration of VZV DNA within the synovial joint cavity might also indicate a possible epiphenomenon of viral replication associated either with the primary immune disturbances of these disorders or with the immune depression produced by therapeutic drugs, which are commonly administered to patients with RA or with ASA. In support of this potential explanation is relevant to point out that the three patients receiving biologic therapy, either rituximab, or infliximab (cases 3 RA, 16 ASA, and 18 ASA; Table 3) were positive for VZV DNA in the synovial fluid.

Although an increased risk for zoster has been reported in RA patients, this feature has been noted mostly in older subjects and in patients under immunosuppressive therapy $[1,3,19,20]$. However, the inverse relation of the risk for RA or ASA in subjects with VZV infections has not been studied, aside from anecdotal reports of cases of transient and ephemeral arthritis at the time of VZV infection or a case of RA remission simultaneous with a disseminated zoster infection [21, 22].

We conclude that HSV1-2 and VZV are occasionally present in patients with RA; VZV is also occasionally present in patients with ASA. No DNA from herpes viruses were found in patients with OA. Although our results do not support the idea of an etiological link between RA or ASA and herpes viruses, a small group of these patients show the actual presence of DNA from these viruses concordant with the inflammatory activity of RA and ASA.

Compliance with ethical standards Ethical reviews were performed, and informed consent approval was granted by the Ethical Committee of Hospital General de Mexico.

Disclosures This work was partly supported by Consejo Nacional de Ciencia y Tecnología, México (CONACYT, Mexico).

Open Access This article is distributed under the terms of the Creative Commons Attribution 4.0 International License (http:// creativecommons.org/licenses/by/4.0/), which permits unrestricted use, distribution, and reproduction in any medium, provided you give appropriate credit to the original author(s) and the source, provide a link to the Creative Commons license, and indicate if changes were made. 


\section{References}

1. Chakravarty EF (2008) Viral infection and reactivation in autoimmune disease. Arthritis Rheum 58:2949-2957

2. Griffiths DJ (2000) Rheumatoid arthritis: a viral aetiology? Hosp Med 61:378-379

3. Reimold A (2010) Viruses and arthritis: new challenges in diagnosis, therapy, and immunization. Am J Med Sci 339:549-556

4. Lossius A, Johansen JN, Torkildsen O, Vartdal F, Holmoy T (2012) Epstein-Barr virus in systemic lupus erythematosus, rheumatoid arthritis and multiple sclerosis-association and causation. Viruses 4:3701-3730

5. Alvarez-Lafuente R, Fernández-Gutiérrez B, de Miguel S, Jover JA, Rollin R, Loza E (2005) Potential relationship between herpes viruses and rheumatoid arthritis: analysis with quantitative real time polymerase chain reaction. Ann Rheum Dis 64:1357-1359

6. Toussitor E, Roudier J (2008) Epstein-Barr virus in autoimmune diseases. Best Pract Res Clin Rheumatol 22:883-896

7. Meron MK, Amital H, Shepshelovich D, Barzilai O, Ram M, Anaya JM et al (2010) Infectious aspects and the etiopathogenesis of rheumatoid arthritis. Clin Rev Allergy Immunol 38:287-291

8. Tzang BS, Tsai CC, Tsay GJ, Wang M, Sun YS, Hsu TC et al (2009) Anti-human parvovirus B19 nonstructural protein antibodies in patients with rheumatoid arthritis. Clin Chim Acta 405:76-82

9. Magnusson M, Brisslert M, Zendjanchi K, Lindh M, Bokarewa MI (2010) Epstein-Barr virus in bone marrow of rheumatoid arthritis patients predicts response to rituximab treatment. Rheumatology 49:1911-1919

10. Mousavi-Jazi M, Boström L, Lövmark C, Linde A, Brytting M, Sundqvist VA (1998) Infrequent detection of cytomegalovirus and Epstein-Barr virus DNA in synovial membrane of patients with rheumatoid arthritis. J Rheumatol 25:623-628

11. Cardone G, Heymann JB, Cheng N, Trus BL, Steven AC (2012) Procapsid assembly, maturation, nuclear exit: dynamic steps in the production of infectious herpesvirions. Adv Exp Med Biol 726:423-439
12. Rosenaud BJ, Schur PH (2009) Association of measles virus with rheumatoid arthritis. J Rheumatol 36:893-897

13. Witt MN, Braun GS, Ihrler S, Schmid H (2009) Occurrence of HSV-1-induced pneumonitis in patients under standard immunosuppressive therapy for rheumatic, vasculitic, and connective tissue disease. BMC Pulm Med 9:22

14. Petrov AV (2005) Frequency of different infectious agents persistence in mononuclear leukocytes of blood and synovial fluid in patients with rheumatoid arthritis. Lik Sprava. Jul-Sep;(5-6):28-32

15. Stahl HD, Hubner B, Seidl B, Liebert UG, van der Jeijden IM, Wilbrink B (2000) Detection of multiple viral DNA species in synovial tissue and fluid of patients with early arthritis. Ann Rheum Dis 59:342-346

16. Sotelo J, Martínez-Palomo A, Ordoñez G, Pineda B (2008) Varicella-zoster virus in cerebrospinal fluid at relapses of multiple sclerosis. Ann Neurol 63:303-311

17. Alcina A, Abad-Grau MM, Fedetz M, Izquierdo G, Lucas M, Fernández O (2012) Multiple sclerosis risk variant HLADRB1*1501 associates with high expression of DRB1 gene in different human populations. PLoS One 7(1):e29819, http://www. plosone.org/article/info\%3Adoi\%2F10.1371\%2Fjournal.pone. 0029819

18. Barcellos LF, Sawcer S, Ramsay PP, Baranzini SE, Thomson G, Briggs $F$ et al (2006) Heterogeneity at the HLA-DRB1 locus and risk for multiple sclerosis. Hum Mol Genet 15:2813-2824

19. Reimold A (2010) Viruses and arthritis: new challenges in diagnosis, therapy, and immunization. Am J Med Sci 339:549-556

20. Strangfeld A, Listing J, Herzer P, Liebhaber A, Rockwitz K, Richter C (2009) Risk of herpes zoster in patients with rheumatoid arthritis treated with anti-TNF-alpha agents. JAMA 307:737-744

21. Agarwal V, Singh R, Chauhan S (2007) Remission of rheumatoid arthritis after acute disseminated varicella-zoster infection. Clin Rheumatol 26:779-780

22. Campalani E, Meenagh GK, Finch MB (2002) Case number 22: an interesting case of herpes zoster in rheumatoid arthritis. Ann Rheum Dis 61:102 